\author{
Aleksandra SZUBART ${ }^{1}$ \\ Barbara FURA ${ }^{2}$
}

\title{
EFEKTY SYSTEMU ZARZĄDZANIA ŚRODOWISKOWEGO ISO 14001 W ORGANIZACJACH W ŚWIETLE WYNIKÓW BADAŃ
}

\begin{abstract}
Artykuł podejmuje problematykę efektów systemu zarządzania środowiskowego (SZŚ) ISO $14001 \mathrm{w}$ przedsiębiorstwach. Na wstępie dokonano przeglądu literatury o tematyce ekoinnowacyjnej, w tym wdrażania SZŚ oraz wskazano główne czynniki motywujące organizacje do stosowania rozwiązań przyjaznych środowisku. Następnie przedstawiono główne korzyści uzyskiwane $w$ przedsiębiorstwach w efekcie stosowania systemu ISO 14001 przytaczane w publikacjach zagranicznych, jak i krajowych. Do najczęściej wskazywanych profitów należą: dostosowanie działalności do obowiązujących przepisów i prawa środowiskowego, wzrost zaangażowania kadry kierowniczej, pracowników czy dostawców w kwestie środowiskowe oraz redukcja wytwarzanych zanieczyszczeń. W drugiej części artykułu przedstawiono wyniki badań własnych przeprowadzonych w drugiej połowie 2014 r. wśród przedsiębiorstw z województwa podkarpackiego mających wdrożony SZŚ ISO 14001. Badania przeprowadzono za pośrednictwem internetu, a dane empiryczne pozyskano z 66 przedsiębiorstw. Celem badania było m.in. poznanie opinii przedsiębiorstw odnośnie do korzyści uzyskiwanych ze stosowania SZŚ ISO 14001. Przedsiębiorcy pozytywnie ocenili wpływ SZŚ na działalność poszczególnych obszarów przedsiębiorstwa. W opinii przedsiębiorstw stosowanie systemu przyczyniło się w największym stopniu do usprawnienia procesu dostawy, za najważniejszą korzyść organizacje uznały poprawę swojego wizerunku. W artykule zweryfikowano hipotezę badawczą głoszącą, że wydłużanie okresu stosowania systemu ISO 14001 przez organizacje pozytywnie wpływa na poziom korzyści generowanych przez ten systemem zarządzania. Przedsiębiorstwa, które stosowały system przez dłuższy czas, korzystniej oceniały jego wpływ na poszczególne aspekty swojej działalności.
\end{abstract}

Słowa kluczowe: system zarządzania środowiskowego, ISO 14001, województwo podkarpackie, przedsiębiorstwa.

\section{WSTEP}

W ciągu ostatnich 30 lat Polska przeszła wiele korzystnych zmian pod względem dbałości o środowisko naturalne. Jeszcze na początku lat osiemdziesiątych aż $11 \%$ powierzchni kraju stanowiły obszary ekologicznego zagrożenia, co doprowadziło do umieszczenia Polski na liście najbardziej zanieczyszczonych krajów europejskich. Kluczowymi działaniami związanymi ze zmianą tego stanu było uchwalenie polityki ekologicznej państwa, wprowadzenie do Konstytucji RP zapisu odnoszącego się do działalności zgodnej z zasadami zrównoważonego rozwoju, przyjęcie „Strategii

\footnotetext{
${ }^{1}$ Mgr inż. Aleksandra Szubart, absolwentka Wydziału Ekonomii Uniwersytetu Rzeszowskiego, email: aleksandra_szubart@interia.pl

${ }^{2}$ Dr Barbara Fura, Wydział Ekonomii, Uniwersytet Rzeszowski, ul. Ćwiklińskiej 2, 35-601 Rzeszów, 17872 1617, autor korespondencyjny: e-mail: bfura@ur.edu.pl
} 
zrównoważonego rozwoju Polski do 2025 r.” oraz wstąpienie Polski do Unii Europejskiej (UE)- dostosowanie się do unijnych dyrektyw związanych $\mathrm{z}$ ochroną środowiska. Zgodnie z długookresową strategią „Europa 2020”do rozwiązań sprzyjających rozwojowi zrównoważonemu krajów członkowskich UE można zaliczyć efektywniejsze korzystanie z zasobów, stosowanie technologii przyjaznych środowisku oraz zmianę wzorców konsumpcji i produkcji ${ }^{3}$. Narzędziem, które w szczególności przyczynia się do stosowania ekologicznych rozwiązań w gospodarce, jest zarządzanie środowiskowe.

Zarządzanie środowiskowe to nowe podejście do zarządzania przedsiębiorstwem, które jest ściśle powiązane $\mathrm{z}$ ogólnym systemem zarządzania występującym $\mathrm{w}$ organizacji ${ }^{4}$. Początki koncepcji sięgają lat osiemdziesiątych XX w. Zarządzanie środowiskowe nakierowane jest na kontrolowanie i sterowanie wpływem działalności przedsiębiorstwa na środowisko naturalne ${ }^{5}$. Kluczem do skutecznego zarządzania środowiskowego $\mathrm{W}$ przedsiębiorstwie są znormalizowane systemy zarządzania środowiskowego (SZŚ). Najbardziej powszechny jest system zarządzania środowiskowego ISO 14001 oraz Eco-Managment and Audit Scheme (EMAS).

$\mathrm{W}$ międzynarodowych badaniach prowadzonych na zlecenie organizacji International Organization for Standardization (ISO) z 2013r. ${ }^{6}$ odnotowano rosnace zainteresowanie normą ISO 14001 wśród organizacji z całego świata. W 2013 r. o 6\% wzrosła liczba wydanych certyfikatów ISO 14001porównaniu z 2012 r. System zarządzania środowiskowego zgodny z wymaganiami normy ISO 14001 wdrożyło ponad 300 tys. organizacji z 171 państw z całego świata. System ten jest najbardziej rozpowszechnionym i przystępnym programem w zakresie zarządzania środowiskowym oddziaływaniem organizacji. Wpływa na to fakt, że norma nie narzuca przedsiębiorstwom odgórnie oczekiwanych rezultatów środowiskowych. Najważniejsze jest podjęcie kroków do bardziej ekologicznego i świadomego prowadzenia działalności. System zarządzania środowiskowego oparty jest na podejściu PDCA (Plan, Do, Check, Act) - Planuj, Wykonaj, Sprawdź, Działaj ${ }^{7}$.

\footnotetext{
${ }^{3}$ B. Ziółkowski, „Europa 2020” w zarządzaniu zrównoważonym rozwojem Unii Europejskiej, „Humanities and Social Sciences”20/1 (2013), s. 123.

${ }_{4}$ A. Marciniuk-Kluska, Zarządzanie środowiskowe $w$ aspekcie zrównoważonego rozwoju gospodarczego, „Zeszyty Naukowe Uniwersytetu Przyrodniczo-Humanistycznego w Siedlcach.Administracja i Zarządzanie" 2013/96, s. 132.

${ }^{5}$ T.N. Phan, K. Baird, The comprehensiveness of environmental management systems: The influence of institutional pressures and the impact on environmental performance, „Journal of Cleaner Production" 2015/160, s. 46-47.

${ }^{6}$ ISO,The ISO Survey of Management System Standard Certifications - 2013 Executive summary, http://www.iso.org/iso/iso-survey (dostęp: 20.07.2015).

${ }^{7}$ W.E. Deming, Nowa ekonomia dla przemystu, rzadu, edukacji, OpexBooks.pl, Wrocław 2012, s. 113-114; C. Comoglio, S. Botta, The use of indicators and the role of environmental management systems forenvironmental performances improvement: a survey on ISO 14001 certifiedcompanies in the automotive sector,„Journal of Cleaner Production” 2012/20, s. 92; B. Fura, Improving ISO 14001 environmental management systems,„,Polish Journal of Environmental Studies”22/6 (2013), s. 1711.
} 
Istotny wpływ na tzw. boom certyfikacyjny, zdefiniowany przez Krystynę Lisiecką ${ }^{8}$, wywiera nie tylko ekologiczny trend obserwowany wśród przedsiębiorstw, ale i zaostrzające sie przepisy prawa środowiskowego. Wiele z firm podejmuje decyzje o wdrożeniu SZŚ na podstawie informacji o licznych korzyśsiach wynikających z jego certyfikacji.

\section{MOTYWY PROEKOLOGICZNEJ DZIALALNOŚCI PRZEDSIEBIORSTW}

Rosnące zainteresowanie ochroną środowiska prowadzi do narastania presji wobec przedsiębiorstw emitujących dużą ilość zanieczyszczeń. Presja ta wywierana jest przez państwo i organizacje proekologiczne, a także przez społeczeństwo - konsumentów i dotyczy konieczności redukcji zanieczyszczeń przez ich emitentów. Co więcej, w wielu krajach znacznie zmniejszyło się przyzwolenie społeczne na brak poszanowania środowiska naturalnego.

Zapoczątkowanie trendu ekologicznego wśród przedsiębiorców przyczyniło się do utworzenia koncepcji ,zielonej gospodarki”. Podstawę tej nowoczesnej koncepcji stanowią: środowisko, gospodarka, polityka społeczna oraz innowacje. Ich połączenie umożliwia poprawę jakości życia, przeciwdziałanie wykluczeniu i dbałość o stan środowiska naturalnego. Zielona gospodarka to taki sposób gospodarowania, w którym już na poziomie decyzji dotyczących produkcji i konsumpcji rozważa się dobro środowiska i społeczeństwa. Wyzwania, jakie stawia zielona gospodarka, to między innymi racjonalne użytkowanie zasobów, ograniczenie presji wywieranej na środowisko, dbałość o ekosystemy (badanie ich stanu, żywotności), troska o dobrobyt społeczny. Postulaty zielonej gospodarki wskazują na potrzebę ,przemodelowania” dotychczasowej gospodarki, co ma umożliwić wyrównanie podziału kosztów i korzyści między wszystkimi użytkownikami środowiska ${ }^{9}$.

Z tematyką aktywności proekologicznej przedsiębiorstw związana jest koncepcja społecznej odpowiedzialności biznesu (CSR, Corporate Social Responsibility). Zgodnie z CSR przedsiębiorcy już na etapie tworzenia strategii rozwoju organizacji uwzględniają aspekty społeczne i środowiskowe. Koncepcja ta jest traktowana zarówno jako działanie dobrowolne, ale i obowiązek wynikający $\mathrm{z}$ obowiązujących przepisów prawnych ${ }^{10}$.Społeczna odpowiedzialność biznesu zyskała uznanie wśród przedsiębiorców, decydentów i innych zainteresowanych stron jako ważny element współczesnego zarządzania mogący ułatwić rozwiązywanie problemów wyłaniających się na styku gospodarki i środowiska.

Wychodząc naprzeciw globalnym problemom środowiskowym, z szeroko rozumianej koncepcji CSR wyodrębniono środowiskową odpowiedzialność biznesu (CER, Corporate Environmental Responsibility). Wśród obszarów działalności przedsiębiorstwa, w których możliwe jest wdrożenie rozwiązań opartych na CER, wymienia się: ekobiuro, ekotransport, edukację ekologiczną pracowników, kontrahentów, dostawców, wpływ na

\footnotetext{
${ }^{8} \mathrm{~K}$. Lisiecka, Znormalizowane systemy zarzadzania, ich certyfikacja a rozwój przedsiębiorstwa, Rola znormalizowanych systemów zarządzania $w$ zrównoważonym rozwoju, „Zeszyty Naukowe Uniwersytetu Ekonomicznego w Poznaniu"2011/166, s. 51.

${ }^{9}$ Główny Inspektorat Ochrony Środowiska, Stan Środowiska w Polsce Raport 2014, Biblioteka Monitoringu Srodowiska, Warszawa 2014, s. 19.

${ }^{10}$ D.K. Zuzek, Społeczna odpowiedzialność biznesu a zrównoważony rozwój przedsiębiorstw, „Zeszyty Naukowe Małopolskiej Wyższej Szkoły Ekonomicznej w Tarnowie”21/2 (2012), s. 198.
} 
bioróżnorodność, ekoefektywność, ekomarketing ${ }^{11}$.Przedsiębiorstwa odpowiedzialne środowiskowo szczególnie mogą korzystać z formalnych rozwiązań, do których należy wspomniany wcześniej SZŚ.

Polscy przedsiębiorcy są zainteresowani wdrażaniem innowacyjnych rozwiązań. Z raportu „Dojrzałość innowacyjna przedsiębiorstw w Polsce” KPMG z 2014r. ${ }^{12}$ wynika, że $78 \%$ średnich i dużych przedsiębiorstw przeprowadzi prace nad innowacjami, $47 \%$ przedsiębiorstw uznaje wdrażanie innowacji za jeden z celów strategicznych, natomiast ponad $80 \%$ firm planuje poszerzenie skali działalności innowacyjnej. Jednym z rodzajów innowacyjnych rozwiązań $w$ przedsiębiorstwach są ekoinnowacje. Badania nad motywacją do wdrażania ekoinnowacji w 2013 r. prowadził między innymi Adam Ryszko. Zgodnie $\mathrm{z}$ wynikami jego badań największą motywacją dla polskich przedsiębiorców jest chęć poprawy wizerunku organizacji, następnie możliwa do uzyskania redukcja kosztów oraz zaostrzające się przepisy prawne. Autor ten wskazuje również bariery hamujące wdrażanie ekoinnowacji. Najczęściej określanymi przez przedsiębiorców barierami są: niepewny zwrot $\mathrm{z}$ zainwestowanego $\mathrm{w}$ innowacyjne rozwiązania kapitału, stosunkowo długi okres zwrotu, problemy $\mathrm{z}$ uzyskaniem dofinansowania oraz niezadowalająca kondycja finansowa przedsiębiorstwa ${ }^{13}$.

Przykładowo w badaniach prowadzonych w Malezji wśród przedsiębiorstw przemysłu opakowań czynnikami, które najbardziej motywowały do działalności proekologicznej (wdrożenie SZŚ ISO 14001),były zainteresowanie stanem środowiska naturalnego przez najwyższe kierownictwo przedsiębiorstwa oraz wychodzenie naprzeciw potrzebom klientów ${ }^{14}$.Inne badania, prowadzone na terenie Indii wśród przedsiębiorstw $\mathrm{z}$ ponad stu różnych sektorów, wykazały, że główną motywacją do wdrożenia SZŚ były: oczekiwany pozytywny wpływ systemu na wizerunek firmy, możliwość zapobiegania zagrożeniom środowiskowym oraz spodziewany wzrost konkurencyjności firmy. Do mniej znaczących czynników motywujących należały zaś dążenie do zmniejszenia kosztów i wzrost innowacyjności należały ${ }^{15}$.

\section{KORZYŚCI Z WDROŻENIA SYSTEMU ZARZĄDZANIA ŚRODOWISKOWEGO W ŚWIETLE DOSTĘPNEJ LITERATURY}

Popularność SZŚ ISO 14001 stale rośnie. Wzrasta również zainteresowanie faktycznym wpływem certyfikacji na przedsiębiorstwa oraz jej oddziaływanie na środowisko. Poziom korzyści wynikający z wdrożenia SZŚ jest przedmiotem badań naukowców z całego świata.

11 P. Grodkiewicz, CER- środowiskowa odpowiedzialność biznesu, „Logistyka Odzysku"15/2(2015), s. 16-18.

12 KPMG, Dojrzałość innowacyjna przedsiębiorstw w Polsce, KPMG w Polsce, 2014, http://kpmglegal.pl/wp-content/uploads/2014/07/Dojrzalosc-innowacyjna-przedsiebiorstw-wPolsce-KPMG-2014.pdf (dostep: 20.07.2015).

13 A. Ryszko, Motywacje i bariery działalności ekoinnowacyjnej przedsiębiorstw w Polsce, „Modern Management Review”21/1 (2014), s. 132.

${ }^{14}$ C.T. Ang, N. Morad, J. Pertanika, Motivating Factors in the Implementation of ISO 14001 in the Packaging Industries in Northern Region of Peninsular Malaysia, „Social Sciences \& Humanities” 22/2 (2014), s. 405.

${ }^{15}$ S. Jain, P. Sharma, N. Singh, Motivations for implementing environmental management practices in Indian industries, „Ecological Economics” 2015/109, s. 1. 
Z badań z 2013 r. prowadzonych na zlecenie ISO wśród 5000 respondentów z 110 krajów(ISO 14001 Continual Improvement Survey 2013) ${ }^{16}$ wynika, że SZŚ ISO 14001 jest istotnym narzędziem dla przedsiębiorców w zakresie spełniania obowiązujących wymagań prawnych, minimalizacji szkodliwego oddziaływania na środowisko oraz zwiększenia zaangażowania kierownictwa i interesariuszy.

Badania prowadzone w Hiszpanii wśród przedsiębiorstw przemysłu motoryzacyjnego wskazują na liczne korzyści wynikające z certyfikacji. Do najważniejszych należą: redukcja zużycia wody, energii i surowców, recykling, redukcja emisji zanieczyszczeń oraz wzrost satysfakcji klientów ${ }^{17}$.

Największą korzyścią osiągniętą $\mathrm{z}$ wdrożenia SZŚ wśród przedsiębiorstw cementowych w Wietnamie okazała się poprawa w kwestii recyklingu. Komponent ten uzyskał średnią ocen 3,7 w czterostopniowej skali (0 - brak poprawy, 4 - bardzo duża poprawa). Przedsiębiorstwa $\mathrm{w}$ Wietnamie odnotowały również poprawę $\mathrm{w}$ zakresie zarządzania niebezpiecznymi odpadami $(3,5)$, transporcie (3), emisji zanieczyszczeń do atmosfery $(2,9)^{18}$. Na podstawie badań prowadzonych w Indiach wśród małych i średnich przedsiębiorstw stwierdzono, że implementacja systemuISO 14001 przyczyniła się do zmniejszenia ilości wytwarzanych odpadów o $25 \%{ }^{19}$.

Korzyści płynące z certyfikacji systemu ISO 14001 były tematem badań między innymi Waldemara Zadwornego. W 2012 r. autor ten przeprowadził badanie wśród 35 przedsiębiorstw z województwa lubelskiego. Największą korzyścią, jaką odnotowały przedsiębiorstwa, była poprawa działalności zgodnie z obowiązującymi przepisami środowiskowymi (89,3\%). Co więcej, znacząco wzrosła świadomość ekologiczna pracowników $(82,1 \%)$ oraz uzyskano dużą poprawę $\mathrm{w}$ kwestii racjonalnego gospodarowania odpadami $(78,6 \%)$. Szybsze i łatwiejsze wykrywanie niezgodności zadeklarowało $67,9 \%$ respondentów. Niemal połowa przedsiębiorstw odnotowała oszczędność materiałów i surowców (46,4\%). W 90\% przedsiębiorstw korzyści wynikające z certyfikacji ISO 14001 przewyższyły poniesione koszty, co pozwoliło stwierdzić, że wdrożenie SZŚ jest przedsięwzięciem efektywnym ekonomicznie ${ }^{20}$.Ekonomiczną efektywność SZŚ potwierdziły również badania Barbary Fury. Około $2 / 3$ z przebadanych przez autorkę organizacji uznało, że korzyści $\mathrm{z}$ funkcjonowania systemu zarządzania przewyższają koszty wdrożenia i utrzymania systemu, wskazując na ekonomiczną efektywność takiego przedsięwzięcia ${ }^{21}$.

16 ISO, ISO $14001 \quad$ Continual Improvement Survey 2013, http://www.iso.org/iso/iso_14001_survey_2013_-_summary_report.pdf(dostęp: 20.07.2015).

17 E. Diaz-Garrido, J.M. Sanchez-Lopez, M.L. Martin-Pena, Analysis of benefits and difficulties associated with firms' Environmental Management Systems: the case of the Spanish automotive industry, ,Journal of Cleaner Production” 2014/70, s. 226.

${ }^{18}$ L. Hens, Q.A. Nguyen, Environmental performance of the cement industry in Vietnam: the influence of ISO 14001 certification, „Journal of Cleaner Production” 2015/96, s. 367.

${ }_{19}$ M. Brueckner, P.K. Padhy, M. Singh, Environmental management system ISO 14001: effective waste minimisation in small and medium enterprises in India, „Journal of Cleaner Production” 2015/102, s. 298

${ }^{20}$ W. Zadworny, Ocena efektywności systemu zarządzania środowiskowego wedtug normy ISO 14001 w przedsiębiorstwach województwa lubelskiego, „Prace Naukowe Uniwersytetu Ekonomicznego we Wrocławiu" 315/2 (2013), s. 419-420, 423.

${ }^{21}$ B. Fura, System zarzadzania środowiskowego a efektywność przedsiębiorstw. Zagadnienia teoretyczne i praktyczne, Wydawnictwo Uniwersytetu Rzeszowskiego, Rzeszów 2011, s. 117-122. 


\section{CEL I METODY BADAWCZE}

Głównym celem artykułu było zbadanie opinii przedsiębiorców na temat efektów uzyskiwanych z certyfikacji ISO 14001. Przedsiębiorcy, oceniając poszczególne obszary działalności przedsiębiorstwa, prezentowali swój poziom zadowolenia odnośnie do korzyści wynikających ze stosowania SZŚ ISO 14001. W niniejszym artykule zweryfikowano następującą hipotezę badawczą:

H:Skala korzyści wynikających ze stosowania SZŚ w przedsiębiorstwach zależy od okresu posiadania certyfikatu ISO 14001.Worganizacjachstosujących system przez dłuższy czas skala obserwowanych korzyści jest większa.

Badanie objęło teren województwa podkarpackiego, a przeprowadzono je w drugiej połowie $2014 \mathrm{r}$. Narzędziem badawczym była anonimowa ankieta, którą rozesłano drogą elektroniczną. Respondenci oceniali wpływ systemu ISO 14001 na jakość produktów, proces dostawy, produkcji i poziom kosztów oraz korzyści z wdrożenia certyfikatu. Oceny dokonano z użyciem 5- lub 7-stopniowej skali mierzącej opinię respondenta w danej kwestii.

Kwestionariusz ankiety rozesłano do 89 przedsiębiorstw z województwa. Ankietę wypełniło 66 przedsiębiorstw. Informacje odnośnie do certyfikowanych organizacji pozyskano ze stron internetowych przedsiębiorstw oraz z portalu eko-net.pl.

\section{CHARAKTERYSTYKA BADANYCH PRZEDSIĘBIORSTW}

Wśród przedsiębiorstw biorących udział $\mathrm{w}$ badaniu największą grupę stanowiły średnie i duże przedsiębiorstwa. Ankietę wypełniło1mikroprzedsiębiorstwo, 6małych, 29 średnich i 30przedsiębiorstw zatrudniających więcej niż 249 pracowników. Firmy były zlokalizowane $\mathrm{w}$ czterech podregionach województwa podkarpackiego (krośnieńskim, przemyskim, rzeszowskim i tarnobrzeskim), z czego największą grupę stanowili przedsiębiorcy podregionu rzeszowskiego (56\%) i krośnieńskiego (29\%). Dominowały przedsiębiorstwa produkcyjne (45) i usługowe (14).Na inny rodzaj działalnościwskazało7przedsiębiorstw. Najwięcej przedsiębiorstw było sklasyfikowanych w sekcji C (przetwórstwo przemysłowe) - 42 oraz F (budownictwo) - 11. Pozostałe działały w sekcjach B, D, E, G, H, L i M. Wśród analizowanych przedsiębiorstw dominowały spółki z ograniczoną odpowiedzialnością (36) oraz spółki akcyjne (25). Na 5 pozostałych przedsiębiorstw składały się 4 spółki jawne i 1 spółka cywilna. Analizując przedsiębiorstwa pod kątem pochodzenia ich kapitału, to wśród badanych organizacji dominowały organizacje z przewagą kapitału polskiego (41),21 przedsiębiorstw zaś było z przewagą kapitału zagranicznego. Pozostałe 4 przedsiębiorstwa wskazały na inną odpowiedź. Wśród badanych przedsiębiorstw przeważały takie, które mogły się poszczycić posiadaniem certyfikatu ISO 14001 przez dłuższy czas. Tylko 9przedsiębiorstw stosowało system nie dłużej niż 3 lata. Dwadzieścia osiem firm posiadało wdrożony SZŚ 4-9 lat, a 29 firm ponad 9 lat.

\section{WPLYW SYSTEMU ZARZADZANIA ŚRODOWISKOWEGO ISO 14001 NA WYBRANE ASPEKTY DZIAŁALNOŚCI ORGANIZACJI}

Wyniki badań własnych w zakresie efektów systemu ISO $14001 \mathrm{w}$ przedsiębiorstwach województwa podkarpackiego prezentują się następująco. Niemal $75 \%$ ankietowanych wskazało na wysoki lub bardzo wysoki wpływ systemu ISO 14001 na zgodność przedsiębiorstwa z prawem środowiskowym. Ponad $60 \%$ objętych badaniem zauważyło duży lub bardzo duży wpływ systemu na wzrost zaangażowania kierownictwa i 
pracowników w kwestie środowiskowe. Ponad $85 \%$ badanych wskazało na co najmniej umiarkowany wpływ systemu na poprawę działalności proekologicznej przedsiębiorstw, zwiększone zadowolenie interesariuszy, jak i łatwiejszą komunikację wewnątrz i na zewnątrz przedsiębiorstwa. Ponadto $64 \%$ ankietowanych zauważyło poprawę efektywności ekologicznej w zakresie procesu dostawy. Uzyskane dane wskazują na znaczny wpływ systemu ISO 14001 na funkcjonowanie przedsiębiorstwa. Wpływ ten zaobserwowano w szczególności w zakresie: spełniania wymagań, do których organizacja się zobowiązała, poprawy wizerunku przedsiębiorstwa, osiągania celów strategicznych oraz integracji z dotychczas funkcjonującymi systemem zarządzania (więcej niż połowa uczestników ankiety wskazała na duży lub bardzo duży wpływ systemu na wymienione kwestie).

W kolejnym etapie badań ocenie poddano wpływ stosowanego SZŚ na następujące obszary działalności firmy ${ }^{22}$ : jakość produktów, proces dostawy, elastyczność produkcji, poziom kosztów produkcji. W $88 \%$ przedsiębiorstw potwierdzono wpływ systemu na poprawę cech produktów. Poprawę wydajności zauważyło $80 \%$ respondentów. Wpływ systemu na poprawę ogólnej jakości produktów pozytywnie oceniło $92 \%$ respondentów. System zarządzania środowiskowego oddziaływał również na proces dostawy realizowany przez przedsiębiorstwa. Poprawę wyników w zakresie zgodności produktu z zamówieniem zauważyło $94 \%$ ankietowanych. Czas realizacji dostawy znacząco polepszył się w $86 \%$ przedsiębiorstw. Poprawę sprawności składania zamówień odnotowało $91 \%$ przedsiębiorców. Spośród ankietowanych $83 \%$ zauważyło poprawę w zakresie elastyczności dostawy. Korzystne zmiany w elastyczności odnośnie do wielkości produkcji zaobserwowało $78 \%$ respondentów. Najsłabiej w zestawieniu oceniono elastyczność w zakresie zmiany asortymentu. Wprawdzie $68 \%$ przedsiębiorstw zauważyło poprawę, jednak $12 \%$ wskazało na pogorszenie sytuacji. Ponadto 75\% badanych pozytywnie oceniło zdolność do kontrolowania kosztów. Zgodnie z udzielonymi odpowiedziami $76 \%$ przedsiębiorców przychylnie oceniło poziom kosztów surowców i materiałów. Negatywną ocenę wystawiło $6 \%$ przedsiębiorstw, zauważając wzrost kosztów. Kontrolę nad całkowitymi kosztami produkcji przychylnie oceniło $74 \%$ firm, podobnie jak w poprzednim przypadku 6\% zauważyło pogorszenie. Najlepiej oceniono bezpośrednie koszty produkcji $-79 \%$ ankietowanych zauważyło ich redukcję, a $5 \%$ wzrost.

W analizie średnich ocen poszczególnych aspektów (tab. 1) najlepsze wyniki uzyskano w obszarze dostawy oraz jakości produktów. Najwyższą średnią $(5,95)$ w 7 stopniowej skali odnotowano $\mathrm{w}$ zakresie ogólnej jakości produktu oraz zgodności produktu $\mathrm{z}$ zamówieniem. Najsłabiej oceniano zagadnienia związane $\mathrm{z}$ poziomem kosztów produkcji.

\footnotetext{
${ }^{22}$ C.J.C. Jabbour, E.M. de Silva, E.L. Paiva, F.C.A. Santos, Environmental management in Brazil: is it a completely competitive priority?,,Journal of Cleaner Production” 2012/21, s. 14.
} 
Tabela 1. Średnia ocena aspektów działalności przedsiębiorstw

\begin{tabular}{|l|l|c|}
\hline \multicolumn{2}{|l|}{ Oceniany aspekt } & Średnia ocena \\
\hline \multirow{2}{*}{$\begin{array}{l}\text { Jakość } \\
\text { produktów }\end{array}$} & Cechy produktu & 5,76 \\
\cline { 2 - 3 } & Wydajność produktu & 5,50 \\
\cline { 2 - 3 } & Postrzegana ogólna jakość produktu & 5,95 \\
\hline \multirow{2}{*}{$\begin{array}{l}\text { Proces } \\
\text { dostawy }\end{array}$} & Sprawność złożenia zamówienia & 5,71 \\
\cline { 2 - 3 } & Szybkość dostawy & 5,67 \\
\cline { 2 - 3 } & Zgodność produktu z zamówieniem & 5,95 \\
\hline \multirow{2}{*}{$\begin{array}{l}\text { Elastyczność } \\
\text { produkcji }\end{array}$} & Elastyczność w zakresie dostawy & 5,64 \\
\cline { 2 - 3 } & Elastyczność w zakresie zmiany wielkości produkcji & 5,45 \\
\cline { 2 - 3 } & Elastyczność w zakresie zmiany asortymentu & 5,24 \\
\hline \multirow{2}{*}{$\begin{array}{l}\text { Poziom } \\
\text { kosztów } \\
\text { produkcji }\end{array}$} & Bezpośrednie koszty produkcji & 5,36 \\
\cline { 2 - 3 } & Całkowite koszty produkcji & 5,26 \\
\cline { 2 - 3 } & Koszty surowców i materiałów & 5,33 \\
\hline
\end{tabular}

Źródło: opracowanie własne.

Respondenci oceniali również korzyści z wdrożenia certyfikatu ISO 14001 (tab. 2). Aż $88 \%$ ankietowanych zauważyło, że certyfikacja wpłynęła na relacje przedsiębiorstwa z klientami. Jedynie 2\% ankietowanych temu zaprzeczyło. Poprawę wizerunku przedsiębiorstwa jako rezultatu posiadania certyfikatu ISO 14001 zadeklarowało 89\% respondentów. $Z$ tym stwierdzeniem nie zgodziło się zaledwie $2 \%$ przedsiębiorstw. Zmniejszenie zagrożeń środowiskowych dzięki posiadaniu certyfikatu odnotowało $85 \%$ organizacji. Jedynie $2 \%$ respondentów zdecydowanie nie zauważyło poprawy w tym zakresie. Zmniejszenie zużycia energii w efekcie wdrożenia SZŚ potwierdziło $61 \%$ ankietowanych. Według 2\% ankietowanych certyfikat nie wywiera wpływu na ten aspekt działalności. Redukcję zanieczyszczeń po wdrożeniu certyfikatu zauważyło $74 \%$ przedsiębiorców. Podobnie jak wcześniej tylko $2 \%$ ankietowanych nie zgodziło się z tym stwierdzeniem.

Tabela 2. Średnia ocena korzyści z wdrożenia certyfikatu ISO 14001

\begin{tabular}{|l|l|c|}
\hline \multicolumn{2}{|l|}{ Oceniany aspekt } & Średnia ocena \\
\hline \multirow{2}{*}{$\begin{array}{l}\text { Korzyści z } \\
\text { wdrożenia } \\
\text { certyfikatu }\end{array}$} & Zmniejszenie zanieczyszczeń & 3,89 \\
\cline { 2 - 3 } ISO 14001 & Zmniejszenie zużycia energii & 3,70 \\
\cline { 2 - 3 } & Zmniejszenie ryzyka zagrożeń środowiskowych & 4,15 \\
\cline { 2 - 3 } & Poprawa wizerunku przedsiębiorstwa & 4,44 \\
\cline { 2 - 3 } & Poprawa relacji z interesariuszami & 4,27 \\
\hline
\end{tabular}

Źródło: opracowanie własne.

Średnia ocen wynikająca z udzielanych odpowiedzi w 5-stopniowej skali wskazuje na najniższy wynik dla zmniejszenia zużycia energii - 3,70, natomiast najwyższy wynik dla poprawy wizerunku przedsiębiorstwa $-4,44$.

W kolejnej części badań analizowano średnie oceny poszczególnych obszarów działalności przedsiębiorstwa i korzyści z certyfikacji w zależności od czasu posiadania certyfikatu przez przedsiębiorstwo (tab. 3).W przedsiębiorstwach, które miały wdrożony certyfikat krócej niż 3 lata, najwyżej oceniono postrzeganą ogólną jakość produktu. 
Przedsiębiorstwa te oceniły również bardzo pozytywnie cechy produktu i zgodności produktu z zamówieniem w procesie dostawy. Organizacje posiadające certyfikat4-9 lat również wysoko oceniły postrzeganą ogólną jakość produktu i zgodność produktu z zamówieniem. Oba aspekty były oceniane najlepiej także wśród firm z okresem certyfikacji dłuższym niż 9 lat. Spośród 12 wymienionych aspektów działalności przedsiębiorstw w 8 przypadkach odnotowano rosnące średnie ocen wraz z czasem posiadania SZŚ. Natomiast we wszystkich przypadkach przedsiębiorstwa mające najdłuższy staż certyfikacji wystawiały najlepsze oceny.

Tabela 3. Ocena jakości produktów, procesu dostawy, elastyczności produkcji, kosztów produkcji a czas posiadania certyfikatu ISO 14001

\begin{tabular}{|c|c|c|c|}
\hline \multirow{3}{*}{ Oceniany aspekt } & \multicolumn{3}{|c|}{ Czas posiadania certyfikatu } \\
\hline & $<3$ lat & 4-9 lat & $>9$ lat \\
\hline & \multicolumn{3}{|c|}{ Średnia ocena } \\
\hline Cechy produktu & 5,78 & 5,61 & 5,90 \\
\hline Wydajność produktu & 5,56 & 5,36 & 5,62 \\
\hline Postrzegana ogólna jakość produktu & 5,89 & 5,89 & 6,03 \\
\hline Sprawność złożenia zamówienia & 5,44 & 5,64 & 5,86 \\
\hline Szybkość dostawy & 5,56 & 5,43 & 5,93 \\
\hline Zgodność produktu z zamówieniem & 5,78 & 5,89 & 6,07 \\
\hline Elastyczność w zakresie dostawy & 5,22 & 5,50 & 5,90 \\
\hline Elastyczność w zakresie zmiany wielkości produkcji & 4,78 & 5,46 & 5,66 \\
\hline Elastyczność w zakresie zmiany asortymentu & 4,67 & 5,14 & 5,52 \\
\hline Bezpośrednie koszty produkcji & 5,00 & 5,25 & 5,59 \\
\hline Całkowite koszty produkcji & 5,00 & 5,07 & 5,52 \\
\hline Koszty surowców i materiałów & 5,11 & 5,14 & 5,59 \\
\hline
\end{tabular}

Źródło: opracowanie własne.

Niezależnie od czasu posiadania certyfikatu poprawa wizerunku przedsiębiorstwa była najwyżej ocenioną korzyścią wynikającą z ISO 14001 (tab. 4).

Tabela 4. Korzyści z wdrożenia certyfikatu ISO 14001 a czas posiadania certyfikatu

\begin{tabular}{|c|c|c|c|}
\hline \multirow{3}{*}{ Oceniana korzyść } & \multicolumn{3}{|c|}{ Czas posiadania certyfikatu } \\
\hline & $<3$ lat & 4-9 lat & $>9$ lat \\
\hline & \multicolumn{3}{|c|}{ Średnia ocena } \\
\hline Zmniejszenie zanieczyszczeń & 3,56 & 3,89 & 4,00 \\
\hline Zmniejszenie zużycia energii & 3,56 & 3,68 & 3,76 \\
\hline Zmniejszenie ryzyka zagrożeń środowiskowych & 3,89 & 4,29 & 4,10 \\
\hline Poprawa wizerunku przedsiębiorstwa & 4,33 & 4,43 & 4,48 \\
\hline Poprawa relacji z interesariuszami & 4,11 & 4,25 & 4,34 \\
\hline
\end{tabular}

Źródło: opracowanie własne.

Z pięciu możliwych do wyboru korzyści w czterech przypadkach odnotowano wzrost średniej oceny wraz $\mathrm{z}$ czasem posiadania certyfikatu. Tylko $\mathrm{w}$ jednym przypadku zmniejszenia ryzyka zagrożeń środowiskowych - najwyższa ocena została uzyskana wśród przedsiębiorstw posiadających system ISO 14001 4-9 lat. 


\section{PODSUMOWANIE}

Wyniki przeprowadzonych badań wskazują, że przedsiębiorcy z województwa podkarpackiego dostrzegają pozytywny wpływ SZŚ ISO 14001 na swoją działalność. Jako efekt stosowania SZŚ odnotowali poprawę w obszarach: jakości produktów, procesu dostawy, elastyczności produkcji oraz poziomu kosztów produkcji, przy czym najwyżej oceniano rezultaty w zakresie procesu dostawy. Natomiast najsłabsze oceny odnotowano w zakresie redukcji kosztów procesu produkcji. Największą korzyścią dla przedsiębiorców z wdrożenia SZŚ była poprawa wizerunku firmy. Respondenci wskazali również na poprawę relacji $\mathrm{z}$ interesariuszami $\mathrm{i}$ zmniejszenie ryzyka zagrożeń środowiskowych. Korzyści, na które badane organizacje rzadziej wskazywały, to redukcja zanieczyszczeń oraz zmniejszenie zużycia energii.

W artykule postawiono hipotezę zakładającą, że wydłużanie czasu stosowania certyfikatu przez organizację pozytywnie wpływa na poziom odnotowanych korzyści. Hipotezę tę potwierdziły prezentowane wyniki badań. Zarówno w poddanych ocenie obszarach działalności przedsiębiorstwa, jak i w zakresie korzyści z certyfikacji najniższe oceny udzielane były przez przedsiębiorstwa posiadające SZŚ najkrócej ( $<3$ lat). Najwyższe oceny niemal zawsze wystawiali przedsiębiorcy posiadający wdrożony certyfikat ISO 14001dłużej niż9 lat. Spośród 12 wymienionych aspektów działalności przedsiębiorstwa w 8 przypadkach poziom zadowolenia respondentów wzrastał wraz z czasem stosowania systemu. Przedsiębiorcy mający certyfikat ISO 14001 ( $<3$ lat, 4-9 lat, >9 lat) zgodnie najwyżej ocenili poprawę w zakresie postrzeganej ogólnej jakości produktu oraz zgodności produktu $\mathrm{z}$ zamówieniem. Na5 uwzględnionych $\mathrm{w}$ kwestionariuszu ankiety korzyści w 4 przypadkach oceny wzrastały wraz z wydłużaniem czasu stosowania systemu ISO 14001. Każda z trzech grup przedsiębiorców najwyżej oceniła wpływ ISO 14001 na poprawę wizerunku przedsiębiorstwa.

Wyniki badań pozwalają wysnuć wniosek, że SZŚ ISO 14001 prowadzi do pozytywnych zmian $\mathrm{w}$ działalności przedsiębiorstw, czego potwierdzeniem sąopinie samych przedsiębiorców. Wraz z upływem czasu posiadania certyfikatu osiągane korzyści rosną. Ponadto certyfikacja szczególnie wpływa na poprawę wizerunku przedsiębiorstwa, co stanowi jedną z głównych motywacji do wdrażania tego systemu zarządzania.

\section{LITERATURA}

[1] Ang C.T., Morad N., Pertanika J.,Motivating Factors in the Implementation of ISO 14001 in the Packaging Industries in Northern Region of Peninsular Malaysia, „Social Sciences \& Humanities”22/2 (2014), s. 395-407.

[2] Brueckner M., Padhy P.K., Singh M.,Environmental management system ISO 14001: effective waste minimisation in small and medium enterprises in India,,Journal of Cleaner Production” 2015/102, s. 285-301.

[3] Comoglio C., Botta S.,The use of indicators and the role of environmental management systems for environmental performances improvement: a survey on ISO 14001 certified companies in the automotive sector, ,Journal of Cleaner Production" 2012/20, s. 92-102.

[4] Deming W.E.,Nowa ekonomia dla przemystu, rzadu, edukacji, OpexBooks.pl, Wrocław 2012. 
[5] Diaz-Garrido E., Sanchez-Lopez J.M., Martin-Pena M.L.,Analysis of benefits and difficulties associated with firms' Environmental Management Systems: the case of the Spanish automotive industry, „Journal of Cleaner Production” 2014/70, s. 220-230.

[6] Fura B., System zarządzania środowiskowego a efektywność przedsiębiorstw. Zagadnienia teoretyczne $i$ praktyczne, Wydawnictwo Uniwersytetu Rzeszowskiego, Rzeszów 2011.

[7] Fura B., Improving ISO 14001 environmental management systems, „Polish Journal of Environmental Studies"22/6 (2013), s. 1711-1721.

[8] Główny Inspektorat Ochrony Środowiska, Stan Środowiska w Polsce Raport 2014, Biblioteka Monitoringu Środowiska, Warszawa 2014.

[9] Grodkiewicz P.,CER - środowiskowa odpowiedzialność biznesu, „Logistyka Odzysku"15/2 (2015), s.16-19.

[10] Hens L., Nguyen Q.A.,Environmental performance of the cement industry in Vietnam: the influence of ISO 14001 certification, „Journal of Cleaner Production" 2015/96, s. 362-378.

[11]ISO: ISO 14001 Continual Improvement Survey 2013, http://www.iso.org/iso/iso_14001_survey_2013__summary_report.pdf(dostęp: 20.07.2015).

[12] ISO: The ISO Survey of Management System Standard Certifications - 2013 Executive summary, http://www.iso.org/iso/iso-survey (dostęp: 20.07.2015).

[13]Jabbour C.J.C.,. De Silva E.M,. Paiva E.L,. Santos F.C.A.,Environmental management in Brazil: is it a completely competitive priority?,,Journal of Cleaner Production" 2012/21, s. 11-22.

[14] Jain S., Sharma P., Singh N.,Motivations for implementing environmental management practices in Indian industries, „Ecological Economics” 2015/109, s. $1-8$.

[15] KPMG, Dojrzałość innowacyjna przedsiębiorstw w Polsce, KPMG w Polsce, 2014, http://kpmglegal.pl/wp-content/uploads/2014/07/Dojrzaloscinnowacyjna-przedsiebiorstw-w-Polsce-KPMG-2014.pdf (dostęp: 20.07.2015).

[16] Lisiecka K.,Znormalizowane systemy zarządzania, ich certyfikacja a rozwój przedsiębiorstwa, Rola znormalizowanych systemów zarządzania $w$ zrównoważonym rozwoju, „Zeszyty naukoweUniwersytetu Ekonomicznego w Poznaniu"2011/166.

[17]Marciniuk-Kluska A., Zarządzanie środowiskowe w aspekcie zrównoważonego rozwoju gospodarczego, „Zeszyty Naukowe Uniwersytetu Przyrodniczo-Humanistycznego w Siedlcach" 2013/96,s. 129-140.

[18] Phan T.N., Baird K., The comprehensiveness of environmental management systems: The influence of institutional pressures and the impact on environmental performance, ,Journal of Cleaner Production”2015/160, s. 4556.

[19] Ryszko A.,Motywacje i bariery działalności ekoinnowacyjnej przedsiębiorstw w Polsce, „Modern Management Review” 21/1 (2014), s. 127-138.

[20]Zadworny W.,Ocena efektywności systemu zarządzania środowiskowego wedlug normy ISO 14001 w przedsiębiorstwach województwa lubelskiego 
„Prace Naukowe Uniwersytetu Ekonomicznego we Wrocławiu” 315/2 (2013), s. 413-424.

[21]Ziółkowski B., „Europa 2020” w zarządzaniu zrównoważonym rozwojem Unii Europejskiej, „Humanities and Social Sciences”20/1 (2013), s. 117-125.

[22]Zuzek D. K.,Społeczna odpowiedzialność biznesu a zrównoważony rozwój przedsiębiorstw, „Zeszyty Naukowe Małopolskiej Wyższej Szkoły Ekonomicznej w Tarnowie"21/2 (2012), s. 197-207.

\section{EFFECTS OF ISO 14001 ENVIRONMENTAL MANAGEMENTSYSTEM IN} ENTERPRISES IN THE LIGHT OF RESEARCH RESULTS

The article presents the issue of effects of ISO 14001 environmental management system (EMS) in the Podkarpackie Province enterprises. It starts with the literature review in terms of eco-innovation activities of enterprises, including the implementation of EMS and identifies the main factors that motivate organizations to apply environmentally friendly solutions. Then it describes the main benefits of ISO 14001 system usage presented in global and domestic literature. According to literature among most frequent profits are: compliance with existing rules and environmental laws, increase in managers' and employees' as well as suppliers' involvement in environmental issues, and pollution reduction. In the second part of the article we present the results of own research carried out in the second half of 2014 among companies from the Podkarpackie Province which implemented ISO 14001 EMS. These studies were conducted with the use of an anonymous questionnaire addressed to people in charge of management systems in the examined enterprises. We sent the survey through the Internet to 89 enterprises. The questionnaire was filled out by 66 companies. The aim of the survey was, among others, to examine the opinions of entrepreneurs with regard to main benefits derived from ISO 14001 adoption and application. Generally, most entrepreneurs positively evaluated the effect of EMSs on their business activities. In the opinion of the enterprises' representatives the ISO 14001 system contributed most to the improvement of the delivery process. The most important benefit achieved from ISO 14001 system adoption was the improvement of enterprises' image. In the presented article we verified a research hypothesis assuming that the extension of the period of ISO 14001 system using in the organizations affected positively on the level of benefits obtained as a result of the system adoption. Companies that used the system for a longer period observed more benefits than those using ISO 14001 standard for a shorter time.

Keywords: environmental management system, ISO 14001, Podkarpackie Province, enterprises.

DOI:10.7862/rz.2016.hss.11

Przesłano do redakcji: wrzesień 2015

Przyjęto do druku: styczeń 2016 